日消外会誌 $38(2): 237 \sim 242,2005$ 年

症例報告

成人腸重積症にて発症した盲腸原発 MALT リンパ腫の 1 例

甲賀病院外科, 同 病理*

安藤 公隆山田誠甲賀 新* 高成 秀樹*

症例は 88 歳の男性で, 頑固な便秘と下腹部痛を主訴として当院を受診した．腹部 CT・US にて右上腹部に target sign を呈する腫瘤影を, 注腸造影ではカニ爪様陰影を認め, 腫瘍を先進 部とする腸重積症と診断されたが，重積は検查中に整復された，大腸内視鏡では盲腸に 1 型腫 瘍を認め, 生検結果は Group 2 であった. 腸重積を伴う盲腸腫瘍の診断で開腹し, 回盲部切除 術(D2)を施行した. 切除標本の病理組織学的検索より盲腸原発 MALT リンパ腫と診断された. 大腸原発悪性リンパ腫による成人腸重積症の報告は, 本邦では 10 例のみ, MALT リンパ腫によ るものは自験例のみと極めてまれである. MALT リンパ腫は基本的に低悪性度であるが, 高悪 性度, リンパ節転移陽性例の報告もある. 大腸 MALT リンパ腫は報告例が少なく症例の集積と 検討が必要であるが，進行例ではリンパ節郭清を伴う切除が必要と考えられた。

\section{はじめに}

Mucosa-associated lymphoid tissue lymphoma (MALT リンパ腫) は 1983 年 Isaacson ら によより 提唱された比較的新しい疾患概念であるが, 大腸 原発 MALT リンパ腫の頻度は低く, まれである. また, 成人腸重積症は小児に比べて発生頻度が低 く, その $80 \%$ は腫瘍性病変をはじめとする器質的 病変に起因するとされている ${ }^{2}$. 今回我々は, 成人 腸重積症にて発症した盲腸原発 MALTリンパ腫 という極めてまれな 1 例を経験したので, 若干の 文献的考察を加えて報告する.

\section{症例}

症例 : 88 歳, 男性

主訴：便秘, 下腹部痛

既往歴：虫垂炎のため虫垂切除術, 十二指腸潰 瘍のため幽門側胃切除術を施行されているが，共 に詳細は不明である。高血圧症で内服加療中.

家族歴：特記すべきことなし.

現病歴：以前から便秘を認めており，緩下剤を 常用していた. 平成 15 年 6 月中旬より便秘が高度 となり, 間歇性の下腹部痛も伴うようになった. 経口摂取不能となり全身の衰弱も認めたため, 6

$<2004$ 年 9 月 22 日受理 $>$ 別刷請求先 : 安藤 公隆 干425-0088 焼津市大覚寺655 甲賀病院外科
Fig. 1 Abdominal CT showed a tumor, $8 \times 5 \times 4 \mathrm{~cm}$ in diameter, with multiple concentric layer structure at right upper abdomen (arrow). No lymph node swelling was observed in abdominal cavity.
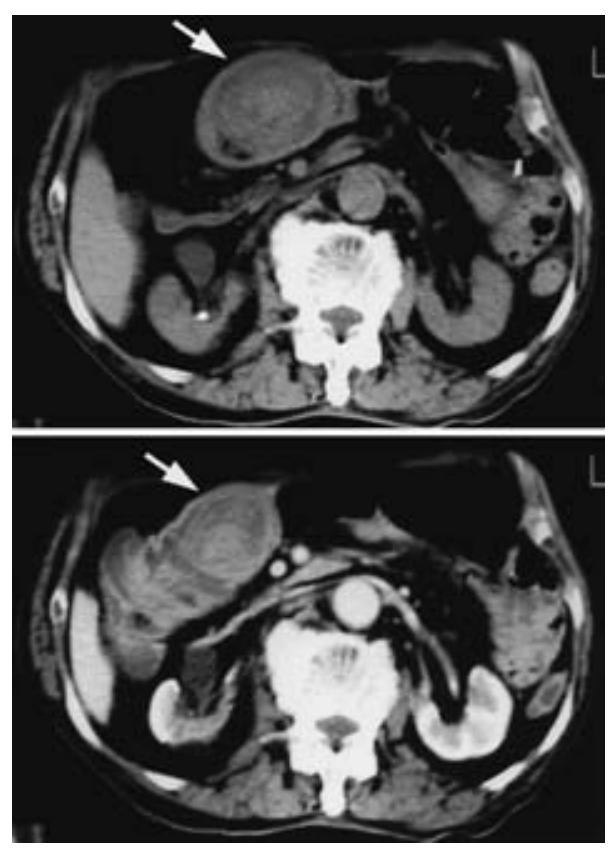

月 30 日に家族に連れられて当院を受診し, 精査加 療目的で入院となった. 
入院時現症：腹部は軽度膨満し, 右季肋部に圧 痛を伴うソーセージ状の腫瘤を触知した．腹膜刺 激症状はなく, 表在リンパ節の腫大は認めなかっ た.

血液生化学検查所見 : 赤血球数 $374 \times 10^{4} / \mathrm{mm}^{3}$, ヘモグロビン $11.7 \mathrm{~g} / \mathrm{dl}$ ， ヘマトクリット $34.5 \%$ の 軽度貧血および CRP $1.6 \mathrm{mg} / \mathrm{dl}$ の軽度上昇を認 め, 腫瘍マーカーは CEA 8.4ng/ml, CA19-9 57 $\mathrm{U} / \mathrm{ml}$, 可溶性インターロイキン 2 レセプター 980

Fig. 2 Ultrasonography revealed target sign (arrow) and hey-folk sign (arrow head) in the mass.

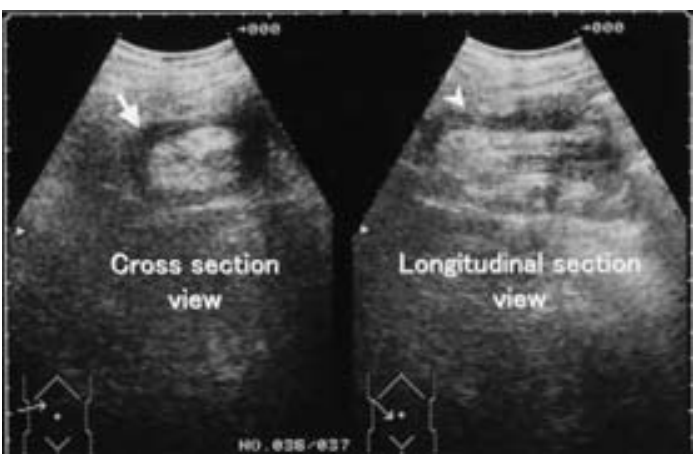

$\mathrm{U} / \mathrm{ml}$ と高值を示した。

腹部 CT 所見 : 結腸肝彎曲部に $8 \times 5 \mathrm{~cm}$ 大の同 心円様構造を示す腫瘤像を認めた。腹腔内リンパ 節には明らかな腫大は認めなかった（Fig. 1).

腹部超音波検査所見：右上腹部の腫瘤は横断像 では target sign を, 縦断像では hay-fork sign を 呈していた（Fig. 2).

注腸造影検查所見：右側横行結腸にカニ爪様陰 影欠損（Fig. 3a）を認めたが，送気により容易に 整復され，盲腸に $5 \mathrm{~cm}$ 大の腫瘤院影 (Fig. 3b) が 描出された。

大腸内視鏡検査所見：盲腸に表面比較的平滑で びらんを伴う黄白色の亜有茎性球状腫瘤を認め た.内視鏡は Bauhin 弁まで挿入され, 腸重積は認 めなかった（Fig. 4)。腫瘍の生検結果は Group 2 であった。

以上の所見より悪性リンパ腫が疑われ，盲腸腫 瘍による腸重積症の診断で 7 月 16 日に手術を施 行した。

手術所見：開腹時, 結腸肝彎曲の口側で上行結 腸に回盲部が引き込まれ重積していた(Fig. 5)が,

Fig. 3 a: Barium enema showed cup-shaped filling defect in the transverse colon (arrow). b: The invagination was released after inflation and the tumor shadow with $5 \mathrm{~cm}$ in diameter was recognized in the cecum (surrounded by arrow head).
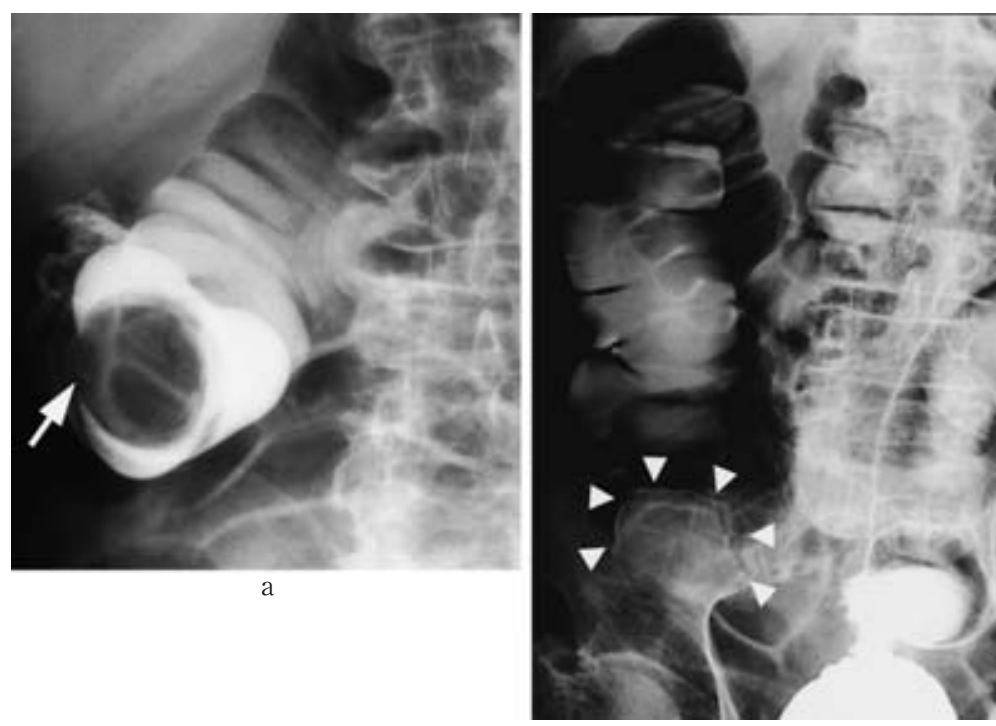
Fig. 4 Colonoscopy demonstrated a smooth-surfaced Type 1 tumor in the cecum (arrow).
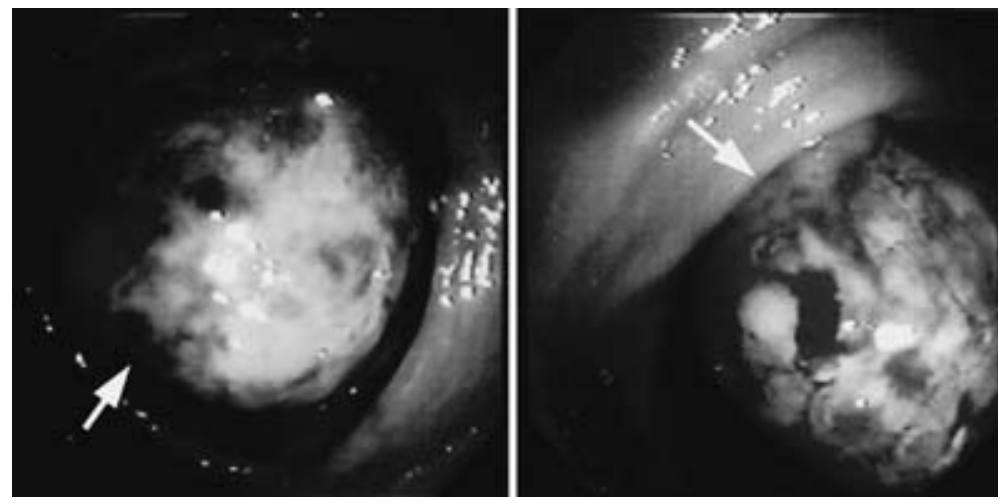

Fig. 5 Intraoperative photograph. An ileocecal invagination (arrow head) without strangulation was observed, however it was easily released.

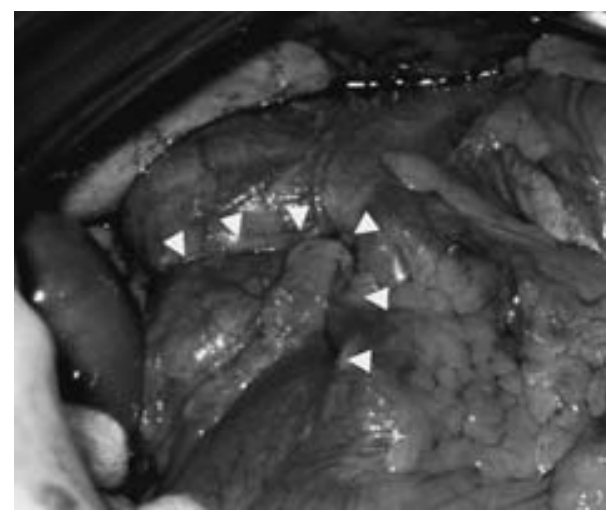

用手的に容易に整復され，盲腸に径 $5 \mathrm{~cm}$ 大の弾性 軟な腫瘤を触知した。重積腸管の壊死はなく，回 盲部切除と 2 群リンパ節郭清を施行した。

切除標本肉眼所見：盲腸に $5.1 \times 5.0 \times 2.7 \mathrm{~cm}$ 大 の表面比較的平滑な亜有荎性 1 型隆起性病変を認 めた (Fig. 6). 腫瘍は弾性硬で, 隆起の頂点の粘 膜面には浅いびらんを認めた，漿膜面には腫瘍の 中心部に浅い陥凹が存在したが，腫瘍の露出は認 めなかった. また, No.201 およびNo.202 のリンパ 節に明かな腫大はみられなかった.

病理組織所見：腸管壁全層にわたって小〜中型 の異型リンパ球 (centrocyte-like cell) の浸潤・増 殖を認め, 腫瘍細胞の上皮内への浸潤, follicular colonization を認めた。 また, 形質細胞浸潤も混在

Fig. 6 Macroscopic findings of resected specimen showed an elevated tumor with $5 \mathrm{~cm}$ in diameter in the cecum.

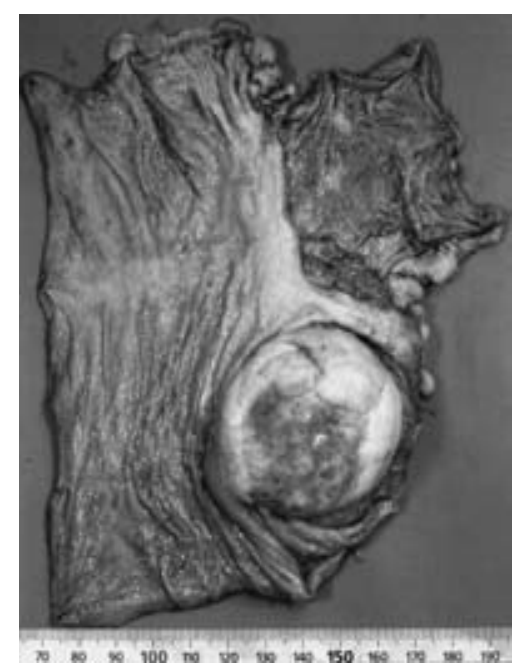

しており, 免疫組織染色では腫瘍細胞は CD3 陰 性, CD 20 (L-26) 陽性, bcl-2 陰性であり, 形質細 胞は $\kappa$ 鎖陽性, $\lambda$ 鎖陰性で, 低悪性度 MALT リン パ腫と診断された（Fig. 7)。なお，2 群リンパ節 （＃202）に1個の転移を認めた.

術後経過 : 創感染・肺炎・肝機能障害を認めた ものの保存的に軽快した。年齢・組織型・全身状 態を考慮し, インフォームドコンセントを得た上, 術後補助療法は施行せず術後 74 日目に退院した.

\section{考察}

大腸原発悪性リンパ腫は大腸墨性腫瘍の $1 \%$ 未 
満34)，消化管原発悪性リンパ腫の $3-15 \%{ }^{5 / 6)}$ と報告 されており，比較的まれな疾患と考えられる。こ の中で MALT リンパ腫は全大腸悪性リンパ腫中 42-90\% を占める ${ }^{7) ~ 9)}$ とされている。一方, 成人腸 重積症の発生頻度は小児に比して少なく全腸重積 症の $5-10 \%$ とされ ${ }^{10)}$, その原因は器質的病変を有 する場合が多く，悪性腫瘍によるものの割合は $42 \%$ ，大腸に限れば悪性腫瘍は $73 \%$ を占める ${ }^{11)}$ と報告されている，大腸原発悪性リンパ腫による 成人腸重積症の本邦報告例は，医学中央雑誌で検 索しえた限りでは，コンピューターによる検索が

Fig. 7 Histological findings ; a : Low-power magnification view showed transmural infiltration of lymphoma cells into the intestinal wall (H.E. $\times 20$ ) . b : High-power magnification view showed proliferation of centrocyte- like cells (H.E. $\times 400)$.

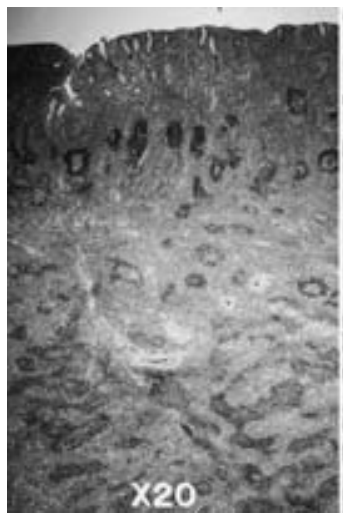

a

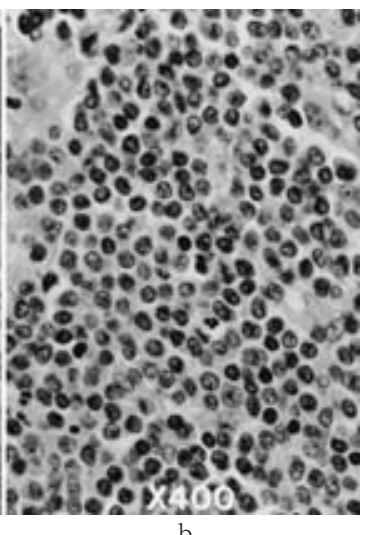

可能な 1983 年以降自験例も含めて 10 例のみであ り，そのうち MALTリンパ腫によるものは自験 例のみ（Table 1) であった。 また, PubMed で検 索した限りでは, 過去 10 年間に欧米で大腸原発悪 性リンパ腫による成人腸重積症の報告はみられ ず, MALT リンパ腫による腸重積症としては回腸 終末原発の MALT リンパ腫の報告が 1 例 ${ }^{12}$ みら れるのみであった。

腸重積の診断には腹部超音波, CT, 注腸造影検 查が有用で, 自験例も注腸造影でのカニ爪様陰影 欠損, CTと超音波での target sign, hay-fork sign といった特徵的所見より容易に診断された.

しかし, 消化管原発悪性リンパ腫の術前診断は比 較的困難であり，大腸悪性リンパ腫の術前臨床診 断の正診率は $19 \%$, 生検における診断率も $42 \%$ 程度と低く ${ }^{7)}$, 疑診まで含めても $\left.65-66 \%{ }^{13}{ }^{14}\right)$ 程度 と報告されている。自験例も悪性リンパ腫を疑い 生検を行ったが, 術前の確定診断には至らなかっ た。

MALT リンパ腫は病理組織学的所見より診断 されるが，自験例では術後の病理組織学的検査所 見より，腫瘍細胞は CD20（L-26）陽性で B-cell 由来であり, centrocyte-like cell の増殖, lymphoepithelial lesion の存在, follicular colonization の存在，形質細胞浸潤の混在といった特徴的所見 が見られたことから MALT リンパ腫と診断され

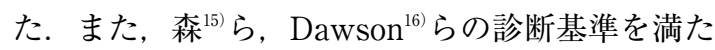
しており，盲腸原発と診断した。

Table 1 Reported cases of intussusception due to malignant lymphoma of the colon in Japan

\begin{tabular}{|c|c|c|c|c|c|c|c|c|}
\hline No. & Year & Author & $\begin{array}{l}\text { Age, } \\
\text { Sex }\end{array}$ & Location & Histological type & Operation & Chemo. & Prognosis \\
\hline 1 & 1988 & Kashimura & $21, \mathrm{M}$ & Colon & diffuse mixed, B cell & unknown & none & Alive 1Y7M \\
\hline 2 & 1990 & Uesugi & $27, \mathrm{M}$ & Appendix & diffuse large, B cell & ileocecal resection & $\mathrm{CHOP}$ & Death $6 \mathrm{M}$ \\
\hline 3 & 1994 & Matsushita & $67, \mathrm{~F}$ & Cecum & diffuse large, B cell & right hemicolectomy & unknown & Alive \\
\hline 4 & 1995 & Takeuchi & $19, \mathrm{M}$ & Cecum & $\begin{array}{l}\text { follicular medium, B } \\
\text { cell }\end{array}$ & ileocecal resection & PBSCT & Alive $4 \mathrm{Y}$ \\
\hline 5 & 1996 & Ushitani & $26, \mathrm{M}$ & Ascending & $\begin{array}{l}\text { diffuse pleomorphic, } \\
\text { B cell }\end{array}$ & right hemicolectomy & VEPA-M & Alive $2 \mathrm{Y}$ \\
\hline 6 & 1996 & Wada & $76, \mathrm{M}$ & Cecum & diffuse mixed, B cell & right hemicolectomy & $\mathrm{CHOP}$ & Alive $6 \mathrm{M}$ \\
\hline 7 & 1999 & Hara & $16, \mathrm{M}$ & Cecum & Burkitt, B cell & unknown & unknown & unknown \\
\hline 8 & 2000 & Hirabayashi & $66, \mathrm{~F}$ & Cecum & unknown & right hemicolectomy & unknown & unknown \\
\hline 9 & 2001 & Koyasaki & $50, \mathrm{~F}$ & Cecum & diffuse large, B cell & ileocecal resection & CHOP & Alive \\
\hline 10 & 2004 & Our case & $88, \mathrm{M}$ & Cecum & $\begin{array}{c}\text { diffuse medium, B cell } \\
\text { (MALT) }\end{array}$ & ileocecal resection & none & $\begin{array}{l}\text { Death 86D from } \\
\text { apoplexy }\end{array}$ \\
\hline
\end{tabular}


大腸 MALT リンパ腫に対しては確立された治 療法は存在せず，悪性リンパ腫に準じて手術，化 学療法, 放射線療法が施行されているのが現状で ある，基本的に低悪性度リンパ腫であり，粘膜下 層以浅の症例においては粘膜切除や局所切除でも 十分であるとする意見 ${ }^{147)}$ がある一方, 悪性転化の 可能性があり, 化学療法に低感受性で, 少ないな がらも再発症例もあることからリンパ節郭清を伴 う腸切除を施行するべきとの意見もある ${ }^{1819}$. 井上 ら ${ }^{14)}$ は大腸 MALT リンパ腫の本邦報告例のうち 手術を施行した 35 例を集計し, 深達度が固有筋層 以深のいわゆる進行した症例の中で, $14.3 \%$ にリ ンパ節転移を認めたと報告している。また，川手 ら ${ }^{20)}$ はn2（+）の MALT リンパ腫に対し D3 のリ ンパ節郭清を施行し 6〜14 年の長期生存を得た 3 症例を報告しており，特に進行例に対するリンパ 節郭清の重要性を示すものと考えられる.

大腸の成人腸重積症では癌腫によるものが $70 \%$ と大多数を占める ${ }^{21)}$ とされてはいるが, 術前 に確定診断が得られていない症例では悪性リンパ 腫を念頭に置く必要がある. 特に腸重積の先進部 となりうるような大きさの進行した症例では, リ ンパ節転移を伴う可能性を考慮し, 癌腫に準じた 可及的なリンパ節郭清を伴う外科的切除を考慮す べきであろう。

大腸 MALT リンパ腫の予後については, 岩下 $ら^{7)}$ は大腸MALTリンパ腫の 5 年生存率は $70.8 \%$ で, MALT でないリンパ腫と比較すると有 意に予後良好であると報告し, 竹下 $ら^{8)}$ 大腸 MALT リンパ腫の低悪性度群は 5 年生存率が $100 \%, 10$ 年生存率は $66 \%$ で予後良好であるが, 高悪性度群では 5 年生存率 $28 \%$ と予後不良例が 多いと報告している.しかし, 大腸 MALT リンパ 腫はいまだ症例数が少なく，発生や進展には不明 な点が多い. 今後, 症例を蓄積し, 腫瘍の悪性度, 進行度とリンパ節郭清や化学療法の必要性, 長期 の治療成績などの検討を重ねる必要がある。

最後に, 本症例の病理組織学的診断, 免疫組織化学的診 断にご協力, ご指導いただいた名古屋市立大学医学部臨床 病態病理学教室教授栄本忠昭先生, 同助教授稲垣宏先生, 同教室吉田めぐみ先生に深謝いたします。

\section{文献}

1) Isaacson $P$, Wright $\mathrm{DH}$ : Malignant lymphoma of mucosa-associated lymphoid tissue. A distinctive type of B cell lymphoma. Cancer 52 : 1410-1416, 1983

2) Sanders GB, Hagan WH, Kinnaird DW : Adult intussusceotion and carcinoma of colon. Ann Surg $147: 796$-804, 1958

3）太田博俊, 西 満正, 上野雅資ほか：腸管悪性リ ンパ腫の診断と治療. 消外 $16: 1419-1428$, 1993

4）太田博俊, 高木國夫, 西 満正ほか：腸管悪性リ ンパ腫の治療と予後. 胃と腸 $24: 529-538$, 1989

5）高木国男：消化管の悪性リンパ腫.内科 60 : 1258-1265, 1987

6) Freeman C, Berg JW, Culter SJ : Occurrence and prognosis of extranodular lymphomas. Cancer $29: 252-260,1972$

7）岩下明徳, 竹下盛重, 竹村 総ほか：原発性大腸 悪性リンパ腫の臨床病理学的検索. 胃と腸 30 : 869-886, 1995

8）竹下重盛, 岩下明徳, 八尾隆史ほか：大腸悪性 B 細胞性リンパ腫の臨床病理学的特徵. 胃悪性 B 細胞リンパ腫との比較を含む. 胃と腸 33 : 405一-414, 1998

9）渡辺英伸, 丸田和夫, 味岡洋一ほか: 消化管悪性 リンパ腫の臓器別特性. 病理学的見地から. 胃と 腸 $33: 299-308,1998$

10) Brayton $D$, Norris WJ : Intussusception in adult. Am J Surg $88: 32-43,1954$

11）坂部 孝: 武藤輝一監. 外科 Mook.35. 成人腸重 積症. 金原出版, 東京, $1984, \mathrm{p} 80-85$

12) Hierlmeier FX, Kolbinger W, Goldbrunner $P$ et al : MALT lymphoma of the ileum as the cause of an enterocolic invagination. DtschMed Wochenschr 120:1435-1438, 1995

13）井原 司, 村上英嗣, 門脇康二ほか：直腸 S 状部 癌を合併した直腸原発 MALT リンパ腫の 1 例. 日臨外会誌 $63: 3008$-3012, 2002

14）井上育夫, 安野憲一, 川野 裕ほか: 大腸 MALT リンパ腫の 2 例. 日臨外会誌 $63: 100-106$, 2002

15）森 茂郎, 山口和克, 喜納 勇ほか：腸原発悪性 リンパ腫の病理一とくに胃およびリンパ節原発 悪性リンパ腫との比較. 癌の臨 $20: 484-489$, 1974

16) Dawson IMP, Cornes' JS, Morson BC : Primary malignant lymphoid tumors of the intestinal tract : Report of 37 cases with a study of factors influencing prognosis. Br J Surg $49: 80-89,1961$

17）山中秀樹, 岡島明子, 杉浦友則ほか：虫垂原発 MALT リンパ腫の1例. 日臨外会誌 63： 1249-1253, 2002

18）辻宗史, 矢野誠司, 高村道生ほか：盲腸原発 
MALTリンパ腫の1例. 日消病会誌 99 ： 1079-1085, 2002

19）関根 毅, 小林輝忠, 出雲俊之 : 大腸 MALT リン パ腫. 臨消内科 $15: 1395$ - 1404,2000

20）川手 進, 関根 毅, 出雲俊之ほか：大腸 Mucosa-
Associated Lymphoid Tissue（MALT）リンパ腫 の 3 切除例. 癌の臨 $44: 367-370,1998$

21）豊見山健, 銘茂 正, 仲間 健 : 回盲部腸重積で 発見された成人 Burkitt型リンパ腫の 1 例. 日臨 外会誌 $61: 2112-2118,2000$

\title{
A Case of Primary MALT Lymphoma of the Cecum Causing Adult Intussusception
}

\author{
Masataka Ando, Makoto Yamada, Shin Kohga* and Hideki Takanari* \\ Department of Surgery and Department of Pathology*, Kohga Hospital
}

A 88-year-old man admitted for severe constipation and lower abdominal pain was found in abdominal CT to have a tumor with multiple concentric rings in the right upper abdomen. Ultrasonography showed a target sign and a hay-fork sign in the tumor. Barium enema showed a cup-shaped filling defect in the transverse colon, but invagination was released after inflation and a tumor shadow $5 \mathrm{~cm}$ in diameter was recognized in the cecum. Colonoscopy showed a smooth-surfaced Type 1 tumor in the cecum, but no definitive diagnosis was obtained from biopsy specimens (Group 2). From these studies, we diagnosed this as intussusception due to a tumor of the cecum, necessitating ileocecal resection with lymph node dissection. Histologically, this was diagnosed as MALT lymphoma invading the serosa with lymph node involvement. The Japanese literature showed only 10 cases of adult intussusception due to primary malignant lymphoma of the colon, including our case, and our case is the first report of intussusception due to primary MALT lymphoma of the colon. In general, MALT lymphoma is a low-grade malignancy, but some cases of MALT lymphoma with high-grade malignant potential or lymph node involvement have been reported. These findings suggest that extensive lymph node dissection, in addition to complete tumor resection, should be done in cases of advanced MALT lymphoma of the colon.

Key words : MALT lymphoma, colon tumor, intussusception

〔Jpn J Gastroenterol Surg 38 : 237-242, 2005]

Reprint requests : Masataka Ando Department of Surgery, Kohga Hospital 655 Daikakuji, Yaizu, 425-0088 JAPAN

Accepted : September 22, 2004 